\title{
Earnings Management Practice in Bangladesh
}

\author{
Ruksana Parvin \\ Lecturer \\ Department of Business Administration \\ German University Bangladesh, Gazipur, Bangladesh \\ Email: parvinruksanaI87@gmail.com
}

\begin{abstract}
This paper detects the existence of Earnings Management (EM) practice in Bangladesh. Total I05 manufacturing companies have been chosen from the different industrial sectors such as pharmaceuticals \& chemicals, food \& allied, cement, engineering, ceramics, tannery, textile \& clothing, paper \& printing, jute, fuel \& power and miscellaneous. The well-known Beneish $M$ score model has been used in detecting EM. The outcome shows that the percentage of non-manipulator companies is greater than manipulator companies except cement, paper \& printing and jute industry. All out $39 \%$ of manufacturing companies are likely manipulator where industry-wise pharmaceuticals \& chemicals $28 \%$, food \& allied $42 \%$, cement $80 \%$, engineering $42 \%$, ceramics $0 \%$, tannery $33 \%$, textile \& clothing $40 \%$, paper \& printing $100 \%$, jute $100 \%$, fuel \& power $25 \%$ and miscellaneous $17 \%$ of manufacturing organizations are likely to be manipulator for 2017. This paper may help the stakeholder for distinguishing between likely and non-likely manipulator companies from the different industrial sectors, making a better decision and formulating policy to reduce the likelihood of manipulation. As Beneish Model is a probabilistic model, it is not unquestionably decisive from the identification that organizations are likely manipulators.
\end{abstract}

Keywords: Beneish Model, Bangladesh, Detecting, Earnings Management, Industry.

\section{Introduction}

EM has become an intrigued zone for financial specialists, loan bosses, reviewers, controllers, analysts and academicians since the flare-up of news about corporate embarrassments, for example, Enron, WorldCom and Waste Management. EM is misrepresenting or manipulating financial related data intentionally for fulfilling the desired goal. EM influences the way toward demonstrating the genuine financial performance of firms through the misuse of accounting policies in the form of financial information that does not reflect the real financial performance of the firms (Talab et al., 20I7). Income increasing EM is more extending than income reducing EM (Beneish, 200I). Some managers manipulate earnings for indicating upward, consistent and ceaseless development in their profits since investors incline toward firms that exhibit consistent development showing upward, steady and continuous growth in their profits because investors prefer firms that demonstrate steady growth (Carruth, 20II).

Distinctive models are utilized for detecting EM, such as Modified Jones model, aggregated accruals Jones model, accrual Models, and the Beneish M-score model. This paper chooses the Beneish model based on a previous literature review for detecting EM. Previously many works of literature applied the Beneish model for detecting the existence of EM such as (Tarjo \& Herawati, 2015; Anh \& Linh, 2016; Paolone \& Magazzino, 2014; Roy \& Debnath, 20I5; Talab et al., 2017), etc. The model is called the Beneish M-score model which comprises of 8 financial ratios to detect either financial reporting distortions resulted from engaging in earnings manipulation (Kamal et al., 2016).

Previously some studies were conducted in Bangladesh. These studies deal with 4 industries such as food and allied, textile, cement and non-financial firms. But previously no study conducted on whole manufacturing companies from different industrial sectors. The purpose of this study is to identify EM practice among whole manufacturing companies from different industrial sectors. This study deals with II industrial sectors.

The results of this paper contribute to help to distinguish between likely and non-likely manipulator manufacturing companies from different industrial sectors. Investors may make a better decision based on this paper's findings. It appears that policymakers or regulators formulating or improving policy for improving financial reporting quality and reducing the likelihood of manipulation.

This paper is as follows. Section 2 is a literature review. Section 3 is the methodology. The analysis and discussion part is explained in section 4 . Section 5 represents the conclusion.

\section{Literature Review}

EM is one sort of managerial activity to change the revealed financial earnings and value of the organization in the short-run with a reason to gain specific welfare outcome and to misdirect investors, by using opportunistic flexibilities which offered by Generally Accepted Accounting Principles (GAAP) (Bhuiyan, 2015). Razzaque et al. (2006) defining EM is that one sort of 
earnings manipulation of accounting outcomes for the objective of creating an alternative impression of corporate financial performance. Manager violates GAAP for presenting financial performance favorably which is called earnings manipulation (Beneish, 1999). EM practicing lessens investor security because security constrains insiders' ability to increase private control benefits, which declines their motivations to veil the organization's financial performance (Leuza et al., 2013).EM makes earning less reliable as estimating firms' financial performance if genuine earnings are managed there is the probability of deceiving all stakeholders and misappropriation of monetary assets in an unhealthy manner (Roy \& Debnath, 2015).

Diverse models were developed for detecting EM. One of the most famous models is the Beneish model. Professor Messod D. Beneish developed a mathematical model in 1999 which ready to ascertain the M score. For detecting EM, the M score utilizes 8 financial ratios (Omar et al., 20I4). Mehta \& Bhavani (20I7) clarified that the Beneish model with two variants. One adaptation is with five variables and another form is with eight variables. Both version models can recognize fraud in earnings manipulation. Beneish model cannot identify manipulation with $100 \%$ accuracy since it is a probabilistic model (Tarjo \& Herawati, 2015). Aghghaleh et al. (2016) argued that the capability of the Dechow F-score model in identifying financial fraud is greater than the Beneish $\mathrm{M}$ score model; whereby it forecasts $73.17 \%$ of financial fraud cases accurately contrasted with $69.51 \%$.

Anh \& Linh (2016) found that 48.4\% of listed non-financial Vietnamese organizations practiced EM during 20I3-20I4 by using the Beneish M-score model. They suggested that the Beneish M-score model is useful techniques for identifying earnings manipulation behaviors of the firms and it additionally could be used for improving financial reporting quality and protecting investors. A study found that half of the listed Italian companies had a low chance of manipulating income by using the Beneish Model (Paolone \& Magazzino, 2014). Tarjo \& Herawati (2015) analyzed the ability of the Beneish model and their result showed that the Beneish model can detect financial fraud. Kamal et al. (2016) found that the Beneish model is reliable in identifying practice of earnings manipulation and financial reporting fraud by $82 \%$ in I4 out of 17 listed firms charged for financial reporting fraud and they also suggested that the Beneish model can be used by auditors, enforcement agencies and researchers as an effective forensic tool to signal potentially fraudulent financial reporting firms in Bursa Malaysia for authorization activity and further examination. Another paper used the M-score model for finding EM engagement in listed Iraqi companies and the result showed that there is the existence of practice EM for most of the listed Iraqi banks (Talab et al., 2017). Roy \& Debnath (2015) used the Beneish model and found that out of the 25 firms from 4 industries only ECL Company is found to not practice EM except I out of IO years and extreme engagement of EM practice is identified in the service industry. They also found that EM has a negative association with profitability and EM has a positive association with liquidity position.

Already a few examinations were led in Bangladesh. Khan \& Akter (2017) investigated the practice of EM by using Beneish Model for the food and allied industry of Bangladesh. They found that I2 out of I4 companies had higher M-score at least for I year from 20II to 20I5. Ahmed \& Azim (2015) analyzed EM for the cement industry in Bangladesh from 2009 to 2013. They used Beniesh Model and found that some companies practice EM because there were signs of highly volatile operating profit and revenue. Razzaque et al. (2006) evaluated the EM in the textile sector of Bangladesh from I992 to 2002. They used the modified Jones Model for detecting EM and revealed that 5 out of I4 firms had significant discretionary accruals in this period. Ahmed \& Naima (2016) evaluated earnings manipulation by using the Beneish model for the non-financial firms in Bangladesh. Their study found that the proportion of likely manipulator company had decreased from the period of 2010 to 2013 and this decreasing behavior indicates that implementation of Corporate Governance 2012 which required several changes in the reporting disclosure. They additionally uncovered that inflating revenues, overstating intangibles and capitalizing costs could serve as signals of EM in firms in Bangladesh.

\section{Methodology}

The data set contains a total of I05 manufacturing companies under II industry for 20I7, which are listed on Dhaka Stock Exchanges. The total sample size represents $56 \%$ of the total population. Industry-wise sample size are pharmaceuticals $\&$ chemicals $62 \%$, food \& allied $67 \%$, cement $71 \%$, engineering $53 \%$, ceramics $20 \%$, tannery industries $50 \%$, textile $\&$ clothing $70 \%$, paper \& printing $50 \%$, jute $33 \%$, fuel \& power $22 \%$ and miscellaneous $50 \%$ of their respective population. The company is selected randomly under different industrial sectors. Data are collected from the company's annual report.

This paper uses the Beneish model for detecting the likelihood of EM. Professor Messod D. Beneish created the Beneish model in 1999 for recognizing plausibility of the presence of EM practice. If the M score is higher than -2.22 (less negative or positive), at that point, the organization is presumably manipulator and on the off chance that $\mathrm{M}$ score is lower than -2.22 (higher negative), at that point the organization is most likely non-manipulator. $\mathrm{M}$ score calculates by 8 variables. The equation is given below:

$$
\begin{gathered}
\text { M Score }=-4.84+0.92^{*} \text { DSRI }+0.528^{*} \mathrm{GMI}+0.404^{*} \mathrm{AQI}+0.892^{*} \mathrm{SGI}+0.1 \mathrm{I} 5^{*} \mathrm{DEPI}-0.172^{*} \mathrm{SGAI}+ \\
4.679^{*} \mathrm{TATA}-0.327^{*} \mathrm{LVGI}
\end{gathered}
$$


Ratios are used as the Beneish model represented in table I. DSRI means Days' sales in receivables index. DSRI index is to be connected with a greater probability that earnings and revenues are overstated (Beneish, I999). GMI means Gross Margin Index. Positively connected with GMI and the possibility of EM (Beneish, I999). AQI means Asset Quality Index. Positive connected between the AQI and the possibility of EM (Beneish, I999). SGI means the Sales Growth Index. Beneish expected that positive connection between the SGI and the possibility of manipulation (Beneish, I999). DEPI means Depreciation Index. Positive connected between the DEPI and the possibility of manipulation (Beneish, I999). SGAI means Sales, General and Administrative Expenses Index. There is a positive connection between the SGAI and the possibility of manipulation (Beneish, 1999). TATA means Total Accruals to Total Assets. There are higher positive accruals (less cash) to be connected with a higher probability of EM (Beneish, I999). LVGI means the Leverage Index. This variable is included to capture incentives in debt covenants for the likelihood of EM (Beneish, 1999).

Table I. Ratio Used as Beneish M-score

\begin{tabular}{|c|}
\hline $\mathrm{DSRI}=\left(\frac{\text { Net receivables } \mathrm{t}}{\text { Sales }_{\mathrm{t}}}\right) /\left(\frac{\text { Net receivables } \mathrm{t}-1}{\text { Sales }_{\mathrm{t}-1}}\right)$ \\
\hline $\mathrm{GMI}=\left(\frac{\text { Sales }_{\mathrm{t}-1}-\text { COGS }_{\mathrm{t}-1}}{\text { Sales }_{\mathrm{t}}}\right) /\left(\frac{\text { Sales }_{\mathrm{t}}-\mathrm{COGS}_{\mathrm{t}}}{\text { Sales }_{\mathrm{t}}}\right)$ \\
\hline $\mathrm{AQI}=\left(1-\frac{\text { Current }_{\text {assets }}+\mathrm{PPE}_{\mathrm{t}}+\text { Securities }_{\mathrm{t}}}{\text { Total Assets }_{\mathrm{t}}}\right) /\left(1-\frac{\text { Current }_{\text {assets }} \mathrm{t}-1+\mathrm{PPE}_{\mathrm{t}-1}+\text { Securities }_{\mathrm{t}-1}}{\text { Total }^{\text {assets }} \mathrm{t}-1}\right)$ \\
\hline $\mathrm{SGI}=\left(\right.$ Sales $\left._{\mathrm{t}}\right) /\left(\right.$ Sales $\left._{\mathrm{t}-1}\right)$ \\
\hline $\mathrm{DEPI}=\left(\frac{\text { Depreciation } \mathrm{t}-1}{\mathrm{PPE}_{\mathrm{t}-1}+\text { Depreciation }_{\mathrm{t}-1}}\right) /\left(\frac{\text { Depreciation } \mathrm{t}}{\mathrm{PPE}_{\mathrm{t}}+\text { Depreciation }_{\mathrm{t}}}\right)$ \\
\hline $\mathrm{SGAI}=\left(\frac{\text { SGA Expenses }_{\mathrm{t}}}{\text { Sales }_{\mathrm{t}}}\right) /\left(\frac{\text { SGA Expenses }_{\mathrm{t}-1}}{\text { Sales }_{\mathrm{t}-1}}\right)$ \\
\hline TATA $=\left(\right.$ Income from Operations $_{t}-$ Cash Flow From Operations $\left.s_{t}\right) /$ Total Assets $s_{t}$ \\
\hline LVGI $=\left(\frac{\text { Current Liabilities } \mathrm{t}+\text { Long Term Liabilities } \mathrm{t}}{\text { Total Assets } \mathrm{t}}\right) /\left(\frac{\text { Current Liabilities } \mathrm{t}-1 \text { +Long Term Liabilities } \mathrm{t}-1}{\text { Total Assets } \mathrm{t}-1}\right)$ \\
\hline
\end{tabular}

\section{Analysis and Discussion}

Source:(Beneish,1999; Khan \& Akter, 2017)

The M-Score for the different industrial sectors of manufacturing companies for 2017 has been calculated which represented in Table 2. Though this model is a probabilistic model, the $\mathrm{M}$ score does not confirm the practice of EM even if the manipulation score is higher than -2.22 .

Table 2. Summary of M-score of Manufacturing Companies from Different Industrial Sectors

\begin{tabular}{cccccc}
\hline Company & M-Score & Company & M-Score & Company & M-Score \\
\hline SQURPHARMA & -1.858 & ARGONDENIM & -2.653 & YPL & -2.1 I 2 \\
\hline BAT & -0.378 & FEKDIL & 0.570 & ZAHINTEX & -3.176 \\
\hline LHBL & -2.217 & QSMDRYCELL & -2.629 & SALVOCHEM & -2.223 \\
\hline RENATA & -2.547 & NTC & -2.079 & FUWANGFOOD & -2.386 \\
\hline OLYMPIC & -1.964 & BENGALWTL & -2.791 & USMANIAGL & -2.8 II \\
\hline MARICO & -3.806 & MATINSPINN & -1.117 & MITHUNKNIT & -12.914 \\
\hline HEIDELBCEM & -2.247 & GENNEXT & -2.999 & RANFOUNDRY & -2.547 \\
\hline ACMELAB & -2.114 & ATLASBANG & 2.552 & ORIONINFU & $-2.56 \mathrm{I}$ \\
\hline IFADAUTOS & -1.995 & OAL & -2.237 & DESHBANDHU & 0.788 \\
\hline RAKCERAMIC & -2.560 & ETL & -1.093 & RDFOOD & -2.572 \\
\hline
\end{tabular}




\begin{tabular}{|c|c|c|c|c|c|}
\hline GLAXOSMITH & -2.534 & CENTRALPHL & -2.504 & HAKKANIPUL & $-\mathrm{I} .538$ \\
\hline BATASHOE & $-2.13 \mathrm{I}$ & GOLDENSON & -6.147 & TALLUSPIN & -2.647 \\
\hline SINGERBD & -2.163 & CMCKAMAL & -2.309 & SINOBANGLA & -2.653 \\
\hline MICEMENT & -0.579 & PDL & $2.62 \mathrm{I}$ & ANWARGALV & -2.938 \\
\hline GPHISPAT & -0.860 & RAHIMAFOOD & -5.880 & APEXSPINN & -3.925 \\
\hline KEYACOSMET & -2.618 & MHSML & $-2.04 \mathrm{I}$ & MONNOCERA & $-3.57 \mathrm{I}$ \\
\hline SQUARETEXT & -2.435 & FAMILYTEX & 4.540 & HRTEX & -3.535 \\
\hline PREMIERCEM & -1.168 & SAIHAMCOT & -1.709 & NORTHERN & -1.603 \\
\hline ACTIVEFINE & -2.767 & DSSL & -2.355 & PHARMAID & -2.618 \\
\hline AMANFEED & -2.425 & MAKSONSPIN & -2.183 & APEXFOODS & I.418 \\
\hline SHASHADNIM & -2.245 & HFL & -2.844 & BANGAS & $-3.0 \mathrm{II}$ \\
\hline APOLOISPAT & $-2.05 \mathrm{I}$ & RAHIMTEXT & -1.197 & GQBALLPEN & -1.742 \\
\hline RNSPIN & -5.793 & APEXTANRY & -2.516 & ALLTEX & -2.689 \\
\hline IBNSINA & -1.775 & ZAHEENSPIN & -2.188 & METROSPIN & $-\mathrm{I} .822$ \\
\hline CONFIDCEM & $-2.19 \mathrm{I}$ & NPOLYMAR & -4.128 & FINEFOODS & $-2.02 \mathrm{I}$ \\
\hline ENVOYTEX & $-2.5 \mathrm{II}$ & HWAWELLTEX & -2.802 & SAFKOSPINN & -3.918 \\
\hline BEACONPHAR & -1.646 & FUWANGCER & 0.090 & AZIZPIPES & -3.427 \\
\hline SHEPHERD & -3.287 & TOSRIFA & -1.802 & FORTUNE & -2.267 \\
\hline KOHINOOR & -3.655 & AL-HAJTEX & -2.434 & JAMUNAOIL & $\mathrm{I} 2.274$ \\
\hline NAVANACNG & -1.988 & SAIHAMTEX & -2.525 & MEGCONMILK & $-\mathrm{I} 4.164$ \\
\hline MSHIPYARD & -2.599 & NURANI & -2.210 & MEGHNAPET & -4.670 \\
\hline MALEKSPIN & -1.116 & NFML & -2.820 & SAVAREFR & -3.035 \\
\hline AFCAGRO & -3.548 & DSHGARME & -3.825 & PADMAOIL & $-57.4 \mathrm{I} 5$ \\
\hline KDSALTD & -2.607 & AMCL(PRAN) & $-3.75 \mathrm{I}$ & BARKAPOWER & -2.282 \\
\hline FARCHEM & -2.427 & DELTASPINN & $-2.3 \mathrm{I} 4$ & POWERGRID & -2.782 \\
\hline
\end{tabular}

Table 3. Number Calculation of Manipulation Status of Manufacturing Company (Industry-wise)

\begin{tabular}{cccc}
\hline Name of the Industry & $\begin{array}{c}\text { Total sample } \\
\text { Company }\end{array}$ & $\begin{array}{c}\text { No. Likely to be } \\
\text { Manipulator Company }\end{array}$ & $\begin{array}{c}\text { No. Likely to be Non- } \\
\text { Manipulator Company }\end{array}$ \\
\hline Pharmaceuticals \& Chemicals & I8 & 5 & I3 \\
\hline Food \& Allied & $\mathrm{I} 2$ & 5 & 7 \\
\hline Cement & 5 & 4 & I \\
\hline Engineering & $\mathrm{I}$ & 8 & $\mathrm{I}$ \\
\hline Ceramics & $\mathrm{I}$ & 0 & 2 \\
\hline Tannery & 3 & $\mathrm{I}$ & $2 \mathrm{I}$ \\
\hline Textile \& Clothing & 35 & $\mathrm{I} 4$ & 0 \\
\hline Paper \& Printing & $\mathrm{I}$ & $\mathrm{I}$ & 3 \\
\hline Jute & $\mathrm{I}$ & $\mathrm{I}$ & 5 \\
\hline Fuel \& Power & 4 & $\mathrm{I}$ & 64 \\
\hline Miscellaneous & 6 & $\mathrm{I}$ &
\end{tabular}

Table 3 shows that industry-wise numbers of likely to be manipulators and non-manipulator manufacturing companies in Bangladesh. Here, the total numbers of likely to be non-manipulator companies are greater than likely to be manipulator companies except cement, paper \& printing and jute industry. A total of 4I out of I05 manufacturing companies are probably 
manipulators. The total percentage of the manipulator and non-manipulator companies represented graphically in figure I where the percentage of likely to be non- manipulator companies is greater than manipulator companies.

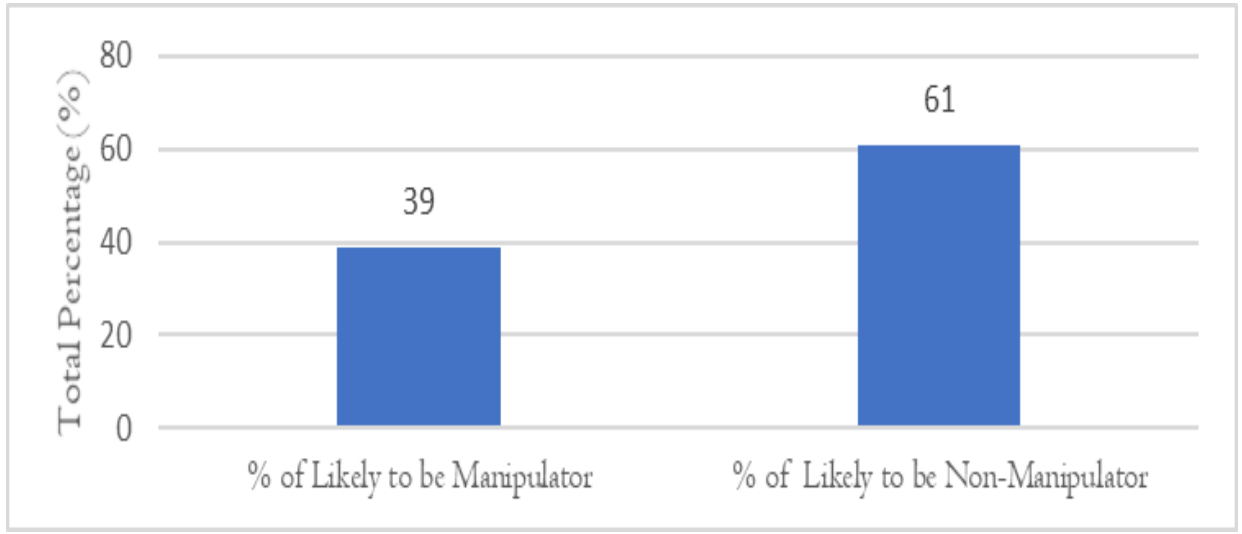

Figure I. Total Percentage (\%) of Manipulation Status of Manufacturing Company

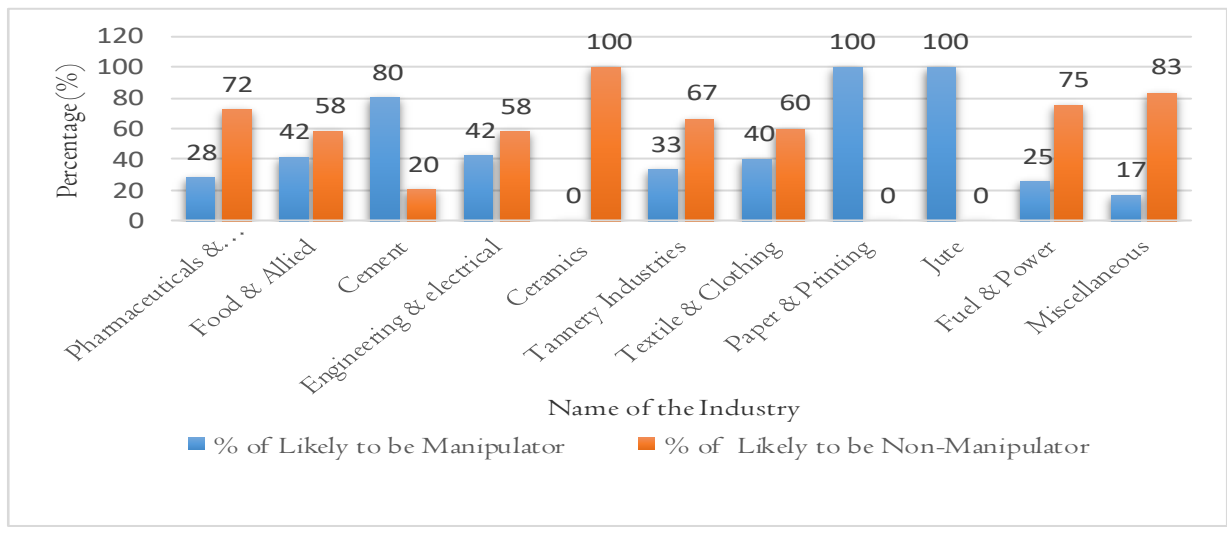

Figure 2. Percentage (\%) of Manipulation Status of Manufacturing Company (Industry Wise)

And the percentage of probable non- manipulator companies are greater than manipulator companies except from cement, paper \& printing and jute industry which graphically represented in figure 2 . This result consistent with previous studies of Bangladesh (Khan \& Akter, 2017; Ahmed \& Azim, 2015; Razzaque et al., 2006; Ahmed \& Naima, 2016). Total 39 \% manufacturing companies are probably manipulator and industry-wise pharmaceuticals \& chemicals $28 \%$, food $\&$ allied $42 \%$, cement $80 \%$, engineering \& electrical $42 \%$, ceramics $0 \%$, tannery industries $33 \%$, textile \& clothing $40 \%$, paper $\&$ printing $100 \%$, jute $100 \%$, fuel \& power $25 \%$ and miscellaneous $17 \%$ of manufacturing companies are likely to be manipulator for 2017 . Paper \& printing and Jute industry $100 \%$ of manufacturing companies are probably engaged in EM practice. I00 \% of the manufacturing company of the ceramics industry is an unlikely manipulator. The Textile and Clothing industrial sector is the largest contributor to economic growth and the national export income. From the Textile and Clothing industry are likely to be a manipulator and non-manipulator companies ratio is $4: 6$.

\section{Conclusion}

This paper deals with the different industrial sectors of manufacturing companies in Bangladesh which practicing EM is measured by using the Beneish $\mathrm{M}$ score model. The percentage of probable non-manipulator companies is greater than manipulator companies except cement, paper \& printing and jute industry. Total $39 \%$ manufacturing companies are probably manipulator and industry-wise pharmaceuticals \& chemicals $28 \%$, food \& allied $42 \%$, cement $80 \%$, engineering $\&$ electrical $42 \%$, ceramics $0 \%$, tannery industries $33 \%$, textile \& clothing $40 \%$, paper \& printing $100 \%$, jute $100 \%$, fuel \& power 25 $\%$ and miscellaneous $17 \%$ of manufacturing companies are probably associate with manipulation for 2017. 
This literature has also some limitations. As the Beneish model is a probabilistic model, it is required addition model for providing a better result. Future studies may overcome this limitation by applying one more model for detecting the existence of EM. This paper only works on a specific year which unable to show a comparative result base on year. Despite the limitation, this paper able to help the regulator in formulating and improving rules \& regulations for protecting the interest of the stakeholder.

\section{References}

Aghghaleh, S. F., Mohamed, Z. M., \& Rahmat, M. M. (2016). Detecting Financial Statement Frauds in Malaysia: Comparing the Abilities of Beneish and Dechow Models, Asian Journal of Accounting and Governance, 7, 57-65.

Ahmed, H., \& Azim, M. (2015). Earnings Management Behavior: A Study on the Cement Industry of Bangladesh, International Journal of Management, Accounting and Economics, 2(4), 265-276.

Ahmed, T., \& Naima, J. (2016). Detection and Analysis of Probable Earnings Manipulation by Firms in a Developing Country, Asian Journal of Business and Accounting, 59-8I.

Anh, N. H., \& Linh, N. H. (2016). Using the M-score Model in Detecting Earnings Management: Evidence from NonFinancial Vietnamese Listed Companies, VNU Journal of Science: Economics and Business, 32 (2), 14-23.

Beneish, M. D. (1999). The Detection of Eamings Manipulation, Financial Analysts Journal, 24-36.

Beneish, M. D. (200I). Earnings Management: A Perspective. Managerial Finance, 27 (12), 3-I7.

Bhuiyan, M. H. (2015). Earnings Management to Exceed Earnings Threshold: Evidence from Bangladesh, Journal of Business Studies, $X X X V I(3), \mathrm{I}-22$.

Carruth, P. J. (20II). Earnings Management: The Role Of Accounting Professionals, International Business \& Economics Research Journal, I (3), 9-I4.

Kamal, M. E., Salleh, M. F., \& Ahmad, A. (2016). Detecting Financial Statement Fraud by Malaysian Public Listed Companies: The Reliability of the Beneish M-Score Model, Journal Pengurusan, 46, 23 - 32.

Khan, A. R., \& Akter, M. (2017). An Analysis of Earnings Management: Evidence from Food \& Allied Industry of Bangladesh, International Journal of Accounting and Financial Reporting, 7(2), 359-372.

Leuza, C., Nandab, D., \& Wysocki, P. D. (2013). Earnings management and investor protection: an international comparison, Journal of Financial Economics, 69, 505-527.

Mehta, A., \& Bhavani, G. (2017). Application of Forensic Tools to Detect Fraud: The Case of Toshiba, Journal of Forensic and Investigative Accounting, $9(\mathrm{I}), 692-7 \mathrm{IO}$.

Omar, N., Koya, R. K., Sanusi, Z. M., \& Shafie, N. A. (2014). Financial Statement Fraud: A Case Examination Using Beneish Model and Ratio Analysis, International Journal of Trade, Economics and Finance,5(2), I84-I86.

Paolone, F., \& Magazzino, C. (2014). Earnings Manipulation among the Main Industrial Sectors Evidence from Italy, Economia Aziendale Online, 5(4), 253-26I.

Razzaque, R. M., Rahman, M. Z., \& Salat, A. (2006). Earnings Management: An Analysis on Textile Sector of Bangladesh, The Cost and Management,34 (5), 5-I3.

Roy, C., \& Debnath, P. (2015). Earnings Management Practices in Financial Reporting of Public Enterprises in India: An Empirical Test with M-Score.

Talab, H. R., Flayyih, H. H., \& Ali, S. I. (2017). Role of Beneish M-score Model in Detecting of Earnings Management Practices: Empirical Study in Listed Banks of Iraqi Stock Exchange, International Journal of Applied Business and Economic Research, 15 (23), 287-302.

Tarjo, \& Herawati, N. (20I5). Application of Beneish M-Score Models and Data Mining to Detect Financial Fraud, Procedia Social and Behavioral Sciences, 211, $924-930$.

\section{Copyrights}

Copyright for this article is retained by the author(s), with first publication rights granted to the journal. This is an open-access article distributed under the terms and conditions of the Creative Commons Attribution license (http://creativecommons.org/licenses/by/4.0/). 